\title{
Okulların Sahip Oldukları Sosyal Sermayeye İlişkin Öğretmen Görüşleri
}

\author{
Fatma KÖYBAŞI ${ }^{*}$, Celal Teyyar UĞURLU**, Ayşad Gonca GÜNER ${ }^{* * *}$
}

Öz: $\mathrm{Bu}$ araştırmanın amacı okulların sahip olduğu sosyal sermayeye ilişkin öğretmen görüşlerini belirlemektir. Çalışma nicel ve nitel yöntemin bir arada kullanıldığı karma yöntem ile yürütülmüştür. Araştırmanın çalışma grubu Giresun ili merkez ilçe ile Şebinkarahisar ilçesinde bulunan toplam 28 okulda görev yapan 196 öğretmen oluşturmuştur. Çalışma grubu ise örneklemden 7 okul seçkisiz yöntemle belirlenerek her birinden ikişer öğretmen olmak üzere toplam 14 öğretmen alınarak oluşturulmuştur. Veri toplama aracı olarak Ersözlü (2008) tarafından geliştirilen sosyal sermaye ölçeği ile yarı yapılandırılmış görüşme formu kullanılmıştır. Nicel veriler üzerinden ortalama ve standart sapma hesaplanmıştır. Ölçek puanlarının bağımsız değişkenlere göre farklılaşıp farklılaşmadığı bağımsız t testi ve ANOVA ile test edilmiştir. Nitel veriler ise içerik analiziyle çözümlenmiştir. Çalışma bulguları, okulların sahip olduğu sosyal sermayeye ilişkin öğretmen görüşlerinin katılmıyorum düzeyinde olduğunu göstermiştir. Ayrıca okulların sahip olduğu sosyal sermayeye dair öğretmen görüşlerinin cinsiyet, kıdem, branş, görev yeri değişkenine göre anlamlı bir farklılık göstermediği; okul türüne göre anlamlı bir farklılık gösterdiği ortaya çıkmıştır. Öğretmenlerle yapılan görüşme sonuçlarına göre okulların sahip oldukları sosyal sermaye bağlamında paylaşılan değerlerin çoğunu insan ilişkileri oluşturmakta ve etkinliklerin çoğu okul dişında gerçekleşmektedir.

Anahtar Kelimeler: Sosyal Sermaye, Örgütsel Güven, Örgütsel Bağl1lık.

\footnotetext{
*Araş. Gör., Cumhuriyet Üniversitesi, Eğitim Fakültesi, fatma_koybasi@ hotmail.com ** Doç. Dr., Cumhuriyet Üniversitesi, Eğitim Fakültesi, celalteyyar@yahoo.com

*** Yük. Lis. Öğr., Giresun Üniversitesi, Şebinkarahisar Sosyal Bilimler Meslek Yüksekokulu, gonca.guner@giresun.edu.tr
} 


\section{The Views of Teachers About Social Capital of The Schools}

Abstract: The aim of this study is to determine the teachers' views related to the social capital that belongs to their schools. This study was conducted by a mixed method type consisting combination of both qualitative and quantitative methods. 196 teachers from 28 different schools in Sebinkarahisar, one of the districts in Giresun, were involved in this study. The study group was designed of 14 teachers, two from each, 7 randomly chosen schools. Data was collected using social capital scale developed by Ersözlü (2008) and a semi-structured interview form created by the researchers. Quantitative data were analyzed by statistical methods and qualitative data were analyzed by the descriptive analysis. Findings were revealed from the blending data obtained from both of qualitative and quantitative methods The results show that the teachers' opinion about social capital of their schools are the level of 'disagree'. Also, teachers' views on social capital are not different in terms of 'gender' 'seniority', 'branch' and 'work place' variables. However, the views of teachers on social capital are different in terms of 'school type' variable. According to the results of the interviews, held with teachers, it has been revealed that most of the values in the context of social capital belonging to schools, are formed with human relations, besides, most of activities are held outside the schools.

Keywords: Social Capital, Organizational Confidence, Organizational Commitment.

\section{Giriş}

Bir görevin tamamlanması için bir veya daha fazla rolün birlikte işe koşulması gerekir. Bireysel, toplumsal ve örgütsel görevlerin tamamlanması o sistem içerisinde bütünlüğü sağlayıcı dengelerin varlığı ile mümkün olabilir. Sistem içerisinde bir taraftan teknik işler yürütülürken diğer taraftan sosyal ilişkilerin de karş1lıklı etkileşimi sağlayacak şekilde olması beklenir. Teknik işlerin yapılmasını sağlayan yöntemler ve kurallar belirli bir 
çerçeveye yerleştirilebilir. Bunun yanı sıra sosyal ortamlarda sosyal etki alanını sağlamak teknik işler kadar net ve açık bir yöntemle gerçekleşebileceğini iddia etmek oldukça zordur.

Güngör (2011) güven, özveri, anlayış gibi değerlerin bireyin çevresindeki sosyal etki alanının oluşumuna katkıda bulunduğunu dile getirmiştir. Bu alan içerisindeki etkileşimi sağlayan karşılıklılık, sosyal ağlar, güven dürüstlük gibi kaynakların yoğunlaşması veya birikimi “sosyal sermaye” kavramıyla açıklanabilir. Sosyal sermaye özellikle 1980’lerden sonra popüler bir kavram olarak birçok araştırmaya konu olmuştur (Woolcock ve Narayan, 2000). Sosyal sermaye bireylerin bir arda güdümlü olarak çalıştığı her alanda (ekonomi, hukuk, işletme, sağlık, eğitim, politika vb.) önemsenen bir kavram olmuştur. Bourdieu (1986) ile başlayan ve günümüzde de Putnam (1993) ile önemini koruyan sosyal sermaye konusuna ilişkin araştırmalar potansiyel bir hareket noktası olarak karşımıza çıkmaktadır.

Bourdieu (1986) sosyal sermayeyi, uzun süreli ve amaçlı olarak kurulmuş olan sosyal ağlara dayalı iletişim ve ilişkilerin sağladığı potansiyel yararların bütünü olarak tanımlamıştır. Demir'e (2009) göre Bourdieu bireyi içinde yaşadığı sosyal çevreyi etkileyen ve ondan etkilenen bir varlık olarak ele almaktadır. Coleman (1988), sosyal sermayeyi karşılıklı ilişkiler ve bunun sonucu oluşan normların kaynağı ve bu kaynağın insan sermayesine katkısı olarak tanımlarken; Putnam (1993) bireyler arasında iletişim ağları, sosyal bağlantılar, karşılıklılık ve güvenin kaynaklık ettiği, işbirliği ve sosyal bütünleşmeye imkân veren bir değer olarak ifade etmektedir. Sosyal sermayeyi oluşturan farklı kavramların bir modelde somut ifadesine olanak verir ki bunlar güven, sosyal ağlar, değer ve normlar ile örgütsel bağl1lık gibi değerleri içerir. Bu değerler sosyal sermaye kümesinde bir alt küme olarak düşünülebilir. Sosyal sermayeyi oluşturan alt boyutlar Şekil 1'de sunulmuştur. 
güven

sosyal ağlar

değer ve normlar

örgütsel bağllık

\section{Şekil 1: Sosyal Sermaye Kavramını İçeren Ögeler}

Sosyal sermaye her örgütte mevcuttur, ama bu mevcudiyetin miktarı örgütlerin yapısal özelliklerine göre çok farklılaşır, tüketilebilir ya da artırılabilir, israf edilebilir ya da üzerine eklenebilir (Töremen, 2002). Eğitim örgütleri, temel öğesi insan olması sebebiyle sosyal sermayeyi oluşturma ve korumaya en çok ihtiyaç duyulan kurumlar olarak ele alınabilir (Ersözlü, 2008). Çankaya ve Çanakçı'ya (2011) göre sosyal sermaye (güven, iletişim, empati, paylaşım vb.) okulların sahip oldukları örtük değerleri arasındadır.

Güner (2012) okulun sosyal sermayesi; okulun amaçlarını gerçekleştirebilmesine, okulun değişime uyum sağlama düzeyine ve mevcut problemleri çözebilmesine yönelik örgüt düzeyinde performans artırıcı bir işleve sahip olduğunu; Orr (1999) ise sosyal sermayenin okullarda sorunların üstesinden gelinmesinde önemli imkânlar ve avantajlar sunduğunu ifade etmiştir.

Okullarda sosyal sermayenin oluşturulması ve korunması için sosyal sermaye ögelerin yer alması gerekir. Bu kavramlardan biri olan güven, sosyal ilişkilerin temelini oluşturan, bireyler arası fedakârlığa dayalı bir duygu olup (Çelik, 2002), örgütler içerisinde işgörenlerin birbirlerine ve çalıştıkları örgüte karşı zamanla geliştirdikleri değer vermeye dayalı duygusal bir güç olarak (Cooper ve Sawaf, 1997) kabul edilmektedir. Töremen (2002) 'e göre, kendinize ve başkalarına güvenmenin ve onlar tarafından da güveniliyor olmanın verdiği güç, yasamda başarıya ulaşmanızı sağlayan en önemli öğelerden biridir. 
Çelik'in (2004) bir araştırmasında öğretmenler arasında güvene dayalı bir ilişki sisteminin oluşturulamaması ve sosyal sermayenin zayıf olması olumsuz okul kültürünün doğmasına yol açtığını ortaya çıkarmıştır. Sosyal sermayenin ana ögelerinden olan güvenin okul kültürü üzerinde etkili olduğu anlaşılmaktadır.

Sosyal sermaye ögelerinden bir diğeri de sosyal ağlardır. Sosyal ağlarda amaç sanal bir "cemaat" oluşturup bunlarla birlikte hareket etme, fikirleri paylaşma, yeni çözümler üretme ve benzeri çalışmalar yapmaktır (Özmen, Aküzüm, Sünkür ve Baysal, 2012). Sosyal sermaye liderleri, okul toplumunu oluşturan sosyal kesimler arasında sosyal ağ ve bağlantıların aktif kılınması yoluyla paylaşılan bir algı ve ortak duygular oluşturarak sosyal sermayenin güçlenmesini ve örgütsel amaçlara hizmet etmesini sağlayabilirler (Kowch, 2004). Sosyal ağlar, okulun amaçlarına odaklı ve hizmete dönük bir şekilde olanak sağlayacağı için sosyal sermayeyi güçlendirici bir öge olarak değerlendirilebilir.

Değer ve normlar da sosyal sermayenin önemli bileşenlerinden biridir. Neyin doğru ve neyin yanlış neyin iyi ve neyin kötü olduğunu belirleyen ölçütler değer olarak tanımlanırken insanların nasıl davranması gerektiğini tanımlayan ve değerlere göre oluşan yazılı olmayan kurallar ve standartlardır (Şişman, 2007). Karşılıklı güven ortamını yakalayan okullarda değerlerin belirlenmesi ve normlara dönüşmesi sosyal ağlarla desteklendiğinde sosyal sermayenin gelişimine açık kapı bırakacaktır.

Ardından sözü edilen bu kavramların yaşatılması ve güçlendirilmesi örgütsel bağlılığa temel atma bakımından kolaylık sağlayabilir. Çalışanın örgüte olan bağlılığı çalıştığı örgütün hedeflerini benimsemesi ve o örgüt içindeki varlığını sürdürmeyi istemesidir (İnce ve Gül, 2005). Neale ve Northcraft'a (1991) göre örgütsel bağlılık genelde üç etken içerir; birincisi, örgütün amaç ve değerlerine olan güçlü inanç, ikincisi, örgüt adına önemli ölçüde çaba sarf etme isteği, üçüncüsü ise örgüt üyeliğini sürdürme hevesidir. Örgütsel bağl1lığı yüksek olan 
kişilerin bir örgütte toplanması o örgütün sosyal sermayesine katkı sağlamasını kolaylaştıracak bir rol oynayabilir.

Okullarda sosyal sermayenin varlığını gösteren durumlar, okul paydaşları arasında karş1lıklı güven ortamın oluşturulması, güvenli ortamda açık ve net değerler bütünün belirlenmesi ve normların oluşturulması, paydaşların sosyal ağ kanalıyla iletişimini devam ettirerek birbirlerinden haberdar olması ve okula bağlılık algılarının olumlu olması olarak siralanabilir.

Sosyal sermayenin unsurları göz önüne alındığında okullara katkı getireceği alanların çeşitli unsurlardan oluştuğu çıkarımı yapılabilir. Bunlar okulun başarısı yanında okulu farklı kılan yapının inşa edilmesinde, karizmatik bir okul olma farkındalığını sağlamada işe koşulacak faktörleri belirlemede etkili olabilir. Okulların sahip olduğu sosyal sermayeye ilişkin öğretmen görüşleri, okulun sosyal sermayesini oluşturan unsurların neler olduğunu betimlemeye dönük veriler sağlayabilir. Ayrıca okulun sosyal sermayesi üzerinden okulun gelişimi için hangi sosyal sermaye unsurların güçlendirilebileceğine ilişkin yol gösterici bilgilere olanak sağlayabilir. Okullarda istenen sosyal sermayenin niteliği ve düzeyi için bu konuda araştırma yapılması önem taşır. $\mathrm{Bu}$ çalışmada okulların sahip olduğu sosyal sermayeye ilişkin öğretmen görüşlerini ortaya çıkarmak amaçlanmıştır.

\section{Yöntem}

Araştırmanın Deseni: Betimsel tarama modelinde olan bu çalışmada karma yöntem kullanılmıştır. Tarama modeli, geçmişte ya da halen var olan bir durumu var olduğu şekliyle betimlemeyi amaçlayan bir araştırma yaklaşımıdır (Karasar, 2002). Green, Krayder ve Mayer (2005) sosyal bilimlerde karma yöntem yaklaşımını, amaçlı olarak iki ya da daha fazla analiz veya veri toplama yolunun aynı araştırmada kullanılmasını olarak tanımlamaktadırlar. $\mathrm{Bu}$ çalışmada nitel ve nicel boyutta veriler toplanarak veri çeşitlemesi yolu ile açımlayıcı sıralı 
karma yöntem deseni seçilmiştir. Öncelikle nicel veriler elde edilmiş sonra nitel verilerle daha derinlemesine verileri anlamlandırarak bütüncül bir yaklaşımla veri analizi yapılmıştır.

Çalışma Grubu: Giresun ili merkez ilçede ve Şebinkarahisar ilçe sınırlarında bulunan ilkokul, ortaokul ve lise olmak üzere toplam 28 okulda görev yapan 208 öğretmendir. Çalışma grubunda yer alan katılımcılara dağıtılan ölçeklerin eksiksiz ve doğru bir şekilde tamamlanması göz önüne alınmıştır. Elde edilen verilerden analiz sürecine katılması uygun görülen 196 tane katılımcının ölçek verileri (\% 94’ü) değerlendirmeye alınmıştır. Nicel boyutta değerlendirmeye alınan çalışma grubunun demografik özelliklerine ait veriler Tablo 1'de sunulmuştur.

Tablo 1. Çalışma Grubuna Ait Demografik Özellikler (Nicel Boyut İçin)

\begin{tabular}{lllll}
\hline Değişkenler & & $\mathrm{f}$ & $\%$ \\
\hline \multirow{2}{*}{ Cinsiyet } & Kadın & 90 & 45,9 \\
\cline { 2 - 5 } & Erkek & 106 & 54,1 \\
\hline \multirow{2}{*}{ Branş̧ } & Sözel & 148 & 75,5 \\
\cline { 2 - 4 } & Sayısal & 48 & 24,5 \\
\hline \multirow{2}{*}{ Görev yeri } & Merkez ilçe & 95 & 48,5 \\
\cline { 2 - 4 } & Şebinkarahisar İlçe & 101 & 51,5 \\
\hline \multirow{2}{*}{ Kıdem } & $1-5$ yıl & 44 & 22,4 \\
\cline { 2 - 5 } & 6-10 yıl & 46 & 23,5 \\
\hline & $11-15$ yıl & 44 & 22,4 \\
\hline \multirow{2}{*}{ Okul türüü } & 16 ve üstü & Ilkokul & 62 & 31,6 \\
\cline { 2 - 5 } & Ortaokul & 87 & 44,4 \\
\cline { 2 - 5 } & Lise & 47 & 24,0 \\
\hline Toplam & & 62 & 31,6 \\
\hline & & 196 & 100 \\
\hline
\end{tabular}

Çalışma grubunda yer alan öğretmenlerin 90’1 $(\% 45,9)$ kadın; 106’sı $(\% 54,1)$ erkek; 148'i (\%75,5) sözel, 48'i $(\% 24,5)$ sayısal branşlarda görev yapan öğretmenlerden oluşmaktadır. Öğretmenlerin 95’i (\% 48,5) Giresun ili merkez ilçede, 101'i (\%51,5) Giresun ili Şebinkarahisar ilçesinde çalışmaktadır. Kıdeme göre mevcut sayısı 1-5 yıl kıdeme sahip olan öğretmenler için 44 (\%22,4), 6-10 y1l kıdeme sahip olan öğretmenler için $46(\%$ 23,5), 11-15 y1l kıdeme sahip olan öğretmenler için $44(\% 22,4)$ ve 16 ve üstü kıdeme sahip olan 
öğretmenler için 62'dir (\%31,6). Ölçek verileri 87'isi $(\% 44,4)$ ilkokul, 47'si $(\% 24,0)$ ortaokul ve 62'si (\% 31,6) liseden olmak üzere toplam 196 tane katılımcıdan elde edilmiştir.

Nitel boyut: Araştırmanın çalışma grubu amaçlı örnekleme yöntemlerinden tipik durum örneklemesi ile belirlenmiştir. Tipik durum örneklemesi seçilmesinin nedeni sosyal sermayenin varlığına ve düzeyine ilişkin durumun ortaya çıkarılmasının amaçlanmasıdır.

Giresun ili Şebinkarahisar ilçe sınırlarında bulunan 7 okuldan ikişer öğretmen olmak üzere 14 öğretmenle görüşülmüş ve öğretmenlerin demografik bilgileri Tablo 2’de gösterilmiştir.

Tablo 2. Çalışma Grubuna Ait Demografik Özellikler (Nitel Boyut İçin)

\begin{tabular}{lllll}
\hline Değişkenler & & $\mathrm{f}$ & $\%$ \\
\hline \multirow{2}{*}{ Cinsiyet } & Kadın & 6 & 42,85 \\
\cline { 2 - 5 } & Erkek & Sözel & 8 & 57,15 \\
\hline \multirow{2}{*}{ Branş } & Sayısal & 10 & 71,43 \\
\hline \multirow{2}{*}{ Medeni hali } & Evli & 4 & 28,57 \\
\cline { 2 - 5 } & Bekar & 7 & 50,00 \\
\hline \multirow{2}{*}{ Kidem } & $1-5$ yıl & 6-10 y1l & 7 & 50,00 \\
\hline Toplam & & 8 & 57,15 \\
\hline
\end{tabular}

Nitel boyutta ele alınan çalışma grubundaki öğretmenlerin 6'sı (\%42,85) kadın, 8'i $(\% 57,15)$ erkek; 10’u $(\% 71,43)$ sözel ve 4'ü $(28,57)$ sayısal branşa sahiptir. Öğretmenlerin 7'si $(\% 50)$ bekar, 7’si (\%50) evli; 8'i (\% 57,15) 1-5 y1l kıdeme sahip, 6’s1 (\%42,85) 6-10 y1l kıdeme sahiptir.

\section{Veri Toplama Araçları}

Nicel Boyut: Araştırmada nicel veriler Ersözlü (2008) tarafından geliştirilen 'Sosyal Sermaye Ölçeği' kullanılmıştır. Ölçek 5 boyutlu 5'li derecelendirilmiş likert tipi 31 
maddeden oluşmaktadır. Ersözlü (2008) çalışmasında ölçeğin iç tutarlılık sayısını.75 ve alt boyutlarının iç tutarlığını ise .60-.89 arasında değer aldığını bulgulamıştır. Bu çalışmada ölçeğin iç tutarlık kat sayısı .80 ve okulumuzdaki öğretmenlerle ilgili önermeler alt boyutu için.87; okuldaki uygulamalarla ilgili önermeler için .88; öğretmenler arası ilişki ağlarıyla ilgili önermeler için .71; öğretmenler odasıyla ilgili önermeler için .66; paylaşılan normlarla ilgili önermeler için ise .45 değerlerine ulaşılmıştır. 5. Boyut için güvenirlik katsayısı bakımından düşük değer almasına rağmen.40’ın üstünde değer aldığı için ve toplam ölçeğin katsayısı yüksek düzeyde olduğu için ölçeğin güvenilirliği kabul edilebilir.

Nitel Boyut: Araştırmanın nitel verileri yarı yapılandırılmış görüşme tekniği ile elde edilmiştir. Literatür taraması yapılarak, sosyal sermaye konusuna ilişkin çalışmalar incelenerek taslak bir görüşme formu hazırlanmıştır. Görüşme formu, eğitim bilimleri alanında iki öğretim üyesi ile soruların içeriği gözden geçirilerek, Türk Dili ve Edebiyatı Bölümü’nden bir uzman ile soruların anlaş1lırlığg irdelenmiştir. Ayrıca çalışma grubunda yer almayan iki öğretmene görüşme formunda yer alan soruların anlaşılırlığı test edilmiştir. Araştırmacı tarafından çalışma grubuna çalışmanın amacı, içeriği hakkında bilgi verilmiştir. Katılımcıların izni alınarak görüşme ses kaydı cihazı ile kaydedilmiştir. Araştırmanın verileri araştırmacı, öğretim üyesi ve uzman tarafından geliştirilen ve 3 soruyu kapsayan bir görüşme formu kullanılarak toplanmıştır. Öğretmenlerle yapılan görüşmeler, 20 dakika sürmüştür. Görüşmelerde öğretmenlerin izni alınarak ses kayıtlarının yapılacağı söylenmiştir. Ses kayıtları yapılmayan öğretmenlerin görüşleri not alınarak gerçekleştirilmiştir. Ses kayıt cihazı ile yapılan görüşmelere ait verilerin deşifresi yapılarak yazılı belgelere dönüştürülmüştür. Yazılı olarak alınan görüşler anında, ses kayıt cihazı ile alınan görüşler ise daha sonra katılımcılarla paylaşılarak eksik ve çıkarılması istenilen kısımların metinden çıkarılması istenilmiştir. Bu çalışma sonucunda yazılı kayıtların denetimi yapılarak üzerinde işlem 
yapılması sağlanmıştır. Öğretim üyeleri ve uzmanlarla yapılan soruların güvenirliği “Güvenirlik=Görüş birliği(/Görüş Ayrılığı+Görüş Birliği) x 100” formülü ile hesaplanmıştır (Miles ve Huberman, 1994). Uyuşum yüzdesi \% 81 olduğu için veri analizi açısından güvenirliğin sağlandığı görülmektedir. Uyuşmayan kodlar gözden geçirilerek veri analizine tabi tutulmamıştır.

\section{Verilerin Analizi}

Nicel Boyut: Öğretmenlerin sosyal sermayeye ve sosyal sermaye ölçeğinin alt boyutlarına ilişkin görüşlerini belirlemek üzere ölçek ortalamaları ve standart sapmaları hesaplanmıştır. Öğretmenlerin bu konuya ilişkin görüşlerinde bağımsız değişkenlere göre farklılık gösterip göstermediğine ilişkin fark testleri (t testi ve ANOVA) kullanılmıştır.

Nitel Boyut: Veriler içerik analizi ile analiz edilmiştir. İçerik analizinde temelde yapılan işlem, öncelikle verileri kodlamak ve kodlanan verileri benzerlikleri açısından temalar çerçevesinde bir araya getirmek daha sonra temalara ilişkin frekans dağılımını oluşturmaktır. Ayrıca gerekli yerlerde doğrudan alıntılar ile desteklenmiştir. Öğretmenlerin sorulara verdikleri sıraya göre Ö1,Ö2,Ö3 vb. kodlama yapılmıştır.

\section{Bulgular}

1.Nicel Boyutla Elde Edilen Bulgular: $\mathrm{Bu}$ bölümde okulların sahip olduğu sosyal sermayeye ilişkin öğretmen görüşlerini ortaya çıkarmaya yönelik ölçek puan ortalamaları, standart sapmalar ile öğretmen görüşlerinin cinsiyet, branş, görev yeri, kıdem ve okul türü değişkenlerine göre farklılık gösterip göstermediğine yönelik yapılan fark testleri sonuçlarına yer verilmiştir. Okullarının sahip olduğu sosyal sermayeye ilişkin öğretmenlerin görüşleri doğrultusunda ölçek puan ortalamaları ve standart sapmaları Tablo 3'te verilmiştir.

Tablo 3. Öğretmenlerin Sosyal Sermaye Ölçek Puanları 


\begin{tabular}{llc}
\hline Boyutlar & $\mathrm{X}$ & $\mathrm{Ss}$ \\
Okulumuzdaki öğretmenlerle ilgili önermeler & 2,0 &, 54 \\
Okuldaki uygulamalarla ilgili önermeler & 2,0 &, 70 \\
Öğretmenler arası iliški ağlarıyla ilgili önermeler & 2,7 &, 68 \\
Öğretmenler odasılyla ilgili önermeler & 2,7 &, 75 \\
Paylaşlan normlarla ilgili önermeler & 2,33 &, 48 \\
Ölçek (Toplam) & 2,23 &, 46 \\
\hline
\end{tabular}

Tablo 3’te görüldüğü gibi sosyal sermaye boyutlarına ve ölçeğe ilişkin ortalamalar 2.0 ila 2.8 arasında bir değer aralığındadır. Sosyal sermayeye ilişkin öğretmen görüşleri katılmıyorum düzeyinde eşdeğer olduğu için öğretmenlerin okulların sahip olduğu sosyal sermayenin varlığına dair oldukça olumsuz görüş bildirdiği görülmektedir.

Öğretmenlerin okulların sahip olduğu sosyal sermayeye ilişkin görüşlerinde cinsiyet, branş, görev yeri ve okul türü değişkenlerine göre anlamlı bir farklılık olup olmadığg $t$ testi ile analiz edilmiş ve Tablo 4'te gösterilmiştir.

Tablo 4. Öğretmen Görüşlerin Cinsiyet, Branş, Görev Yeri Değişkenlerine Göre Analizi

\begin{tabular}{lllllll}
\hline Değişken & & N & X & ss. & t & p \\
\hline Cinsiyet & Kadın & 90 & 2,26 &, 49 &, 804 &, 42 \\
& Erkek & 106 & 2,21 &, 43 & & \\
\hline Branş & Sözel & 148 & 2,30 &, 54 & 1,17 &, 24 \\
& Sayısal & 48 & 2,21 &, 43 & & \\
\hline \multirow{2}{*}{ Görev yeri } & İl merkezi & 95 & 2,21 &, 52 & -575 &, 56 \\
& İlçe merkezi & 101 & 2,25 &, 39 & & \\
\hline
\end{tabular}

Tablo 4'te görüldüğü üzere öğretmenlerin okulların sahip olduğu sosyal sermayeye ilişkin görüşlerinde cinsiyet, branş, görev yeri ve okul türü değişkenlerine göre anlamlı bir farklılık bulunmamıştır ( $>$ >.05). Okulların sahip olduğu sosyal sermayeye ilişkin cinsiyet, branş, görev yeri ve okul türü değişkenlerine göre öğretmenlerin görüşlerinin benzer olduğu ifade edilebilir. Öğretmenlerin okulların sahip olduğu sosyal sermayeye ilişkin görüşlerinin kıdem ve okul türü değişkenlerine göre anlamlı bir farklılık olup olmadığı ANOVA testi ile analiz edilmiş ve Tablo 5'te verilmiştir. 
http://dx.doi.org/10.23891/yyuni.2017.4

ISSN:1305-2020

Tablo 5. Öğretmen Görüşlerin Kıdem ve Okul Türü Değişkenlerine Göre Analizi

\begin{tabular}{|c|c|c|c|c|c|c|c|c|c|c|c|}
\hline \multirow{6}{*}{$\begin{array}{l}\bar{\Xi} \\
\bar{\nabla} \\
\beth\end{array}$} & & $\mathrm{N}$ & $\mathrm{X}$ & Ss & Var. Kay. & KT & $\mathrm{Sd}$ & $\mathrm{KO}$ & $\mathrm{F}$ & $\mathrm{p}$ & Fark \\
\hline & $1-5 y_{1}$ & 44 & 2,3 &, 48 & Grup içi & 1,1 & 3 & ,37 & & & - \\
\hline & $6-10 \mathrm{y} 1 \mathrm{l}$ & 46 & 2,1 &, 47 & Grup arası & 40,6 & 192 & 21 & & & \\
\hline & $11-15$ yll & 44 & 2,1 &, 49 & Toplam & 41,9 & 195 & & 1,78 &, 15 & \\
\hline & 16 ve üstü & 62 & 2,2 &, 41 & & & & & & & \\
\hline & İlkokul (i) & 87 & 2,4 &, 51 & Grup içi & 4,1 & 2 & 2,09 & & & $1>0$ \\
\hline$\exists$ & Ortaokul(o) & 47 & 2,1 &, 53 & Grup arası & 37,7 & 193 & ,19 & 10,6 &, 00 & $1>\mathrm{i}$ \\
\hline & Lise (l) & 62 & 2,1 &, 30 & Toplam & 41,9 & 195 & & & & \\
\hline
\end{tabular}

Tablo 5’teki verilere göre okulların sahip olduğu sosyal sermayeye ilişkin öğretmen görüşlerinde kıdem değişkenine göre anlamlı bir farklılık ortaya çıkmazken ( $p>.05)$; okul türü değişkenine göre anlamlı bir farklılık olduğu görülmüştür $(\mathrm{p}<.05)$. Farklılığın hangi gruplar arasında olduğunu belirlemek üzere önce dağılımın homojenliği test edilmiştir. Levene istatistik değeri 12,09 ve $\mathrm{p}<.000$ ile dağılımın homojen olmadı̆̆ tespit edildiği için Posthoc testlerinden Tamhane testi kullanılmıştır. Farklılığın kaynağı lise olup lisedeki sosyal sermayeye ilişkin puanların ortaokul ve ilkokula göre daha yüksek olduğu ortaya çıkmıştır.

2. Nitel Boyutla Elde Edilen Bulgular: Sosyal sermaye ögelerinden biri olan değerler bakımından öğretmenlere okul ortamında öğretmenler arası öne çıkan değerlerin neler olduğu sorulmuştur. Bu soruya ilişkin verilen cevaplar olumlu ve olumsuz değerler olmak üzere iki kategoriye ayrılmıştır. Bu kategorilere ilişkin verilen temalar ve frekans dağılımları Tablo 6'da özetlenmiştir.

Tablo 6. Okul Ortamında Öğretmenler Arası Öne Çııan Değerler ve Frekans Dağılımı

\begin{tabular}{|c|c|c|c|c|c|c|}
\hline Tema & $\begin{array}{l}\text { Olumlu değerler } \\
\text { kategorisi }\end{array}$ & Kodlamalar & $\mathrm{f}$ & $\begin{array}{l}\text { Olumsuz } \\
\text { değerler } \\
\text { kategorisi }\end{array}$ & Kodlamalar & f \\
\hline & Sayg1-sevgi & Ö1,2,3,4,7,9,11,12,13,14 & 10 & Gruplaşmalar & Ö2,5,6,8 & 4 \\
\hline 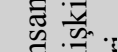 & Yardımlaşma & Ö1,3,4,5,7,11,12,13,14 & 9 & Güvensizlik & Ö5,6 & 2 \\
\hline$\Xi .=$ & İletişim & Ö3,4,5,7,9,12,13,14 & 8 & Saygısızlık & Ö1,6 & 2 \\
\hline
\end{tabular}


http://dx.doi.org/10.23891/yyuni.2017.4

ISSN:1305-2020

\begin{tabular}{|c|c|c|c|c|c|c|}
\hline & Güven & Ö3,4,10,,12,13,14 & 6 & İş tatminsizliği & Ö5,6 & 2 \\
\hline & Fikir alışverişi & Ö5,11,12,14 & 4 & İletişimsizlik & Ö6,10 & 2 \\
\hline & Okula bağlanma & Ö4,12,14 & 3 & Moral bozmak & Ö6 & 1 \\
\hline & Özveri & Ö3,13 & 2 & Huzursuzluk & Ö6 & 1 \\
\hline & Huzur & Ö4,12 & 2 & Örnek olmama & Ö6 & 1 \\
\hline & Empati & Ö4, 12 & 2 & Çıkar ilişkisi & Ö6 & 1 \\
\hline & Toplam & & 46 & & & 16 \\
\hline & Eşitlik & Ö3,9,12,13,14 & 5 & Dayatma & Ö5 & 1 \\
\hline & Karara katılma & Ö3,12,13 & 3 & Eşitsizlik & Ö6 & 1 \\
\hline & Sorun çözmek & Ö1,4,14 & 3 & Adam kayırma & Ö6 & 1 \\
\hline & Denge & Ö4,12,14 & 3 & İdeolojik bakış & Ö6 & 1 \\
\hline & İnsiyatif & Ö4,2,14 & 3 & Sorun çıkarma & Ö6 & 1 \\
\hline స్ర & Sorumluluk & Ö1,14 & 2 & & & \\
\hline & Toplam & & 19 & Toplam & & 5 \\
\hline & Anlayış & Ö3,4,5,12,13 & 5 & & & \\
\hline & Hoşgörü & Ö1,2,5,7,12 & 5 & & & \\
\hline$\frac{\bar{v}}{\pi}$ & Güdüleme & Ö3,13,14 & 3 & & & \\
\hline N & Taktir edilme & Ö4 & 1 & & & \\
\hline & Toplam & & 14 & & & \\
\hline & Paylaşım & Ö3,11,12,13,14 & 5 & & & \\
\hline & Arka çıkma & Ö6,12,14 & 3 & & & \\
\hline & Ortak tavır & Ö1,12 & 2 & & & \\
\hline 苍 & Espri & Ö7,12 & 2 & & & \\
\hline & Toplam & & 12 & & & \\
\hline
\end{tabular}

Öğretmenlere sosyal sermayenin unsurlarından biri olan değerlere yönelik görüşleri alınmıştır. Okul ortamında öğretmenler arası öne çıkan olumlu değerler kategorisinde çoğunlukla insan ilişkileri temasında $(\mathrm{f}=46)$ yoğunlaştı̆̆ dile getirilen değerler saygı ve sevgi ( $\mathrm{f}=10$ ), yardımlaşma $(\mathrm{f}=9)$ ve iletişim $(\mathrm{f}=8)$ 'dir. İnsan ilişkileri temasına ilişkin katılımcıların görüşlerinden bazıları şu şekildedir:

Ö3: "Yönetici ve öğretmenlerin iletişimde saygıya dayalı bir yaklaşımda ve emir cümlelerinin olmadığı bir iletişim tarzı motivasyonumuzu artırmaktadır”.( iletişim değeri).

Ö12: 'Tecrübeli ve kıdemli öğretmenlerimizin, mesleğe yeni başlamış öğretmenlere karş1 tutumu öğretici ve yardıma dayalıdır”. (yardımlaşma değeri).

Bir sonraki sırada öne çıkan olumlu değerler kategorisinde adalet teması ( $\mathrm{f}=19)$ yer almıştır. Adalet temasında en çok eşitlik $(f=5)$ değerine odaklanılmıştır. Diğer olumlu değerin nezaket (f=14) temasında ağırlık kazandığı görülmüştür. Nezaket temasında üzerinde en çok 
durulan değerler anlayış $(\mathrm{f}=5)$ ve hoşgörü $(\mathrm{f}=5)$ 'dür. Üçüncü sırada öne çıkan tema dostluk $(\mathrm{f}=12)$ olup bu temada arka çıkma $(\mathrm{f}=3)$, ortak tavır $(\mathrm{f}=2)$ ve espri $(\mathrm{f}=2)$ değerleri dile getirilmiştir. Nezaket temasına ilişkin katılımcı görüşü şu şekildedir:

Ö1: “Okulda var olan herhangi bir problemi birlikte çözümleyip ortak bir tavır almaktayız”. (dostluk teması-paylaşım değeri).

Okul ortamında öğretmenler arası öne çıkan olumsuz değerler kategorisinde iki tema ortaya çıkmış ve çoğunu insan ilişkileri $(\mathrm{f}=16)$ teması oluşturmuştur. Olumsuz insan ilişkileri temasında en çok gruplaşmalar $(\mathrm{f}=4)$ olduğu görülmüştür. Daha sonra ise güvensizlik $(\mathrm{f}=2)$, saygısızlık ( $\mathrm{f}=2)$, iş tatminsizliği $(\mathrm{f}=2)$ ve iletişimsizlik $(\mathrm{f}=2)$ değerleri sıralanmıştır. Olumsuz değerler kategorisinde yer alan diğer tema adalet $(\mathrm{f}=5)$ olup adalet temasında dayatma $(\mathrm{f}=1)$, eşitsizlik ( $\mathrm{f}=1$ ), adam kayırma ( $\mathrm{f}=1$ ), ideolojik bakış $(\mathrm{f}=1)$, ve sorun çıkarma ( $\mathrm{f}=1)$ değerleri üzerinde durulmuştur. Olumsuz insan ilişkileri temasına ait katılımcı görüşlerinden biri şu şekildedir.

Ö5: "Sosyal açıdan oluşan gruplaşmalar birtakım dayatmalara da neden olmakta". (insan ilişkileri-gruplaşmalar).

2. Sosyal sermaye ögelerinden biri olan normlar bakımından öğretmenlere okul ortamında öğretmenler arası ilişkilerde ortaklaşa yapılan etkinliklerin neler olduğu sorulmuştur. $\mathrm{Bu}$ soruya ilişkin verilen cevaplar olumlu ve olumsuz değerler olmak üzere iki kategoriye ayrılmıştır. Daha sonra bu kategorilere ilişkin verilen temalar ve frekans dağılımları Tablo 7'de gösterilmiştir.

Tablo 7. Okulda Öğretmenler Arası İlişkilerde Ortaklaşa Yapılan Etkinliklerin Frekansları

\begin{tabular}{|c|c|c|c|c|c|}
\hline Tema & & & Tema & & \\
\hline Okul içi etkinlik & Kodlamalar & $\mathrm{f}$ & Okul dışı etkinlik & Kodlamalar & $\mathrm{f}$ \\
\hline Yardım Kamp. & Ö3,4,7, 13 & 4 & Piknik & Ö1,4,5,7,8,12,14 & 7 \\
\hline
\end{tabular}




\begin{tabular}{llllll}
\hline Öğrenci etk. & Ö3,4,13,14 & 4 & Sohbet & Ö1,2,4,7,8,12,14 & 7 \\
\hline Resmi top. & Ö4,6,14 & 3 & Gezmek & Ö7,8,9,11,14 & 5 \\
\hline Konferans vb. & Ö3,13,14 & 3 & Kahvalt1 & Ö1,2,4,5,11,12 & 5 \\
\hline Törenler & Ö4,6,14 & 3 & Spor & Ö2,7,9,12,14 & 5 \\
\hline \multicolumn{2}{r}{} & & Eğlence & Ö4,9,12,14 & 4 \\
\hline Toplam & & Ev ziyareti & Ö1,4,12,14 & 4 \\
\hline
\end{tabular}

Sosyal sermayenin unsurlarından biri olan normlar konusunu ele almak için öğretmenlere okul ortamında öğretmenler arası ilişkilerde ortaklaşa yapılan etkinliklerin neler olduğu sorulmuştur. Öğretmenlerin ortaklaşa yapılan etkinliklere verdikleri ifadeler okul içi ve dışı etkinlikler olma üzere iki tema altında toplanmıştır. Öğretmenlerin görüşlerine göre okul dışı etkinlikler ( $\mathrm{f}=37)$ okul içi etkinliklere $(\mathrm{f}=17)$ göre daha sıklıktadır. Okul dış1 etkinliklerden pikniğe gitme $(\mathrm{f}=7)$ ve sohbet etme $(\mathrm{f}=7)$ daha sik tekrarlanan etkinlikler arasında yer almıştır. Bunun yanı sıra en az yapılan etkinlikler arasında eğlence $(f=4)$ ve ev ziyaretleri ( $\mathrm{f}=4$ ) yer almıştır. Okul içi etkinlikler arasında yapılan etkinlikleri öğretmenler, yardım kampanyaları $(f=4)$, öğrenci etkinlikleri $(f=4)$, resmi toplantılar $(f=3)$, konferans vb. katılım ( $\mathrm{f}=3$ ) ve törenler $(\mathrm{f}=3$ ) olarak ifade etmişlerdir. Bu konuya ilişkin öğretmen görüşleri şu şekildedir:

Ö14: “'Okulda öğretmen arkadaşlarla anlaşarak hafta sonlarında pikniğe gideriz.’'(Okul dış1 etkinlik-piknik).

Ö3: “Bir yere yardım için para toplanacak veya başka bir iş yapılacak ise bir araya gelerek ortaklaşa bir şeyler yapmaya çalışırız.' (Okul içi etkinlik-yardım kampanyası).

\section{Tartışma, Sonuç ve Öneriler}

Okulların sahip olduğu sosyal sermayeye ilişkin öğretmen görüşleri katılmıyorum düzeyindedir. $\mathrm{Bu}$ bulguya dayanarak okulların sosyal sermayeye gösterdikleri ilginin az olduğunu sosyal sermaye konusuna fazla önem verilmediği anlaşılmaktadır. Eğitim 
örgütlerinde önemli etkileri olacağı düşünülen sosyal sermayenin gelişimi açısından ulaşılan sonuç istenilen düzeyde olmadığı yorumu yapılabilir.

Öğretmenler arası ilişki ağlarıyla ilgili önermeler ve öğretmenler odasıyla ilgili önermeler boyutlarındaki puanların diğer boyutlardaki puanlardan daha yüksek olduğu görülmüştür. Ayrıca öğretmenler arası öne çıkan değerler olarak da insan ilişkileri teması üzerinde diğer temalara göre daha fazla durulmuştur.

Nicel yöntemle ulaşılan bulgu nitel yöntemle ulaşılan bulgu ile örtüştüğü görülmüştür. $\mathrm{Bu}$ bağlamda sosyal sermayenin gelişimi için insan ilişkilerinin önemli olduğu ifade edilebilir. Ayrıca, dostluk, nezaket ve adalet değerlerinin öğretmenler arasında ön planda yer aldığı ortaya çıkmıştır. Eğitim örgütlerinin doğası gereği insan ögesi önem taşır. Sosyal sermaye ögeleri arasında yer alan değerler kategorisinde de insan ilişkilerinin ağırlık kazanması olası bir durumdur. Çalışma bulguları bu durumu desteklemektedir. Bunun yanında nezaket, dostluk ve adaletin öne çıkan değerler olması öğretmenlerin okul ortamında bu değerleri önemsemesi demektir. Bu bağlamda okul ortamında karşılaşılan olumlu değerlerin ortaya çıkması eğitim örgütlerine katkı sağlayacağı söylenebilir. Çankaya ve Çanakçı (2011)'nın yapmış oldukları araştırma sonucunda, sosyal sermayenin iletişim ve güven alt boyutları ile öğretmenlerin motivasyon düzeyini anlamlı ve pozitif yönde yordadığı görülmüştür.

Allik ve Realo (2004); Newton (2001) ve Palgi ve Moore (2004) yaptıkları çalışmalarda benzer şekilde; örgüt içi iletişime önem verilen ve güven ortamının yüksek düzeyde olduğu özel işletmelerde, iş görenlerin motivasyonlarının da yüksek düzeyde olduğunu tespit etmişlerdir Yapılan araştırmalar ve bu araştırmada tespit edilen sonuçlar karşılaştırıldığında, sosyal sermayeye ait unsurların (iletişim, güven) motivasyon üzerinde anlamlı etkisi olduğu görülmektedir. 
Okulların sahip olduğu sosyal sermaye düzeyinin okul türü lise olan okullarda diğer okul türlerine göre daha fazla olduğu ortaya çıkmıştır. Şahin ve Ada (2011)'nın sosyal ve entellektüel sermayelerin okullardaki düzeylerinin, "okul türü” değişkeni bazında ilköğretim okul yöneticilerine göre “iyi düzeyde”, ortaöğretim yöneticilerine göre ise “orta düzeyde' olduğu bulgusu ile bu araştırma bulgusu çelişmektedir. Araştırma yapılan örneklemin veya yöntemin farklı olması farklı bulguların doğmasına imkan vermiş olabilir. Bu bağlamda okul türü değişkenin sosyal sermayeye etkisi araştırılması gereken konulardan biri olabilir.

Araştırma bulgulardan bir diğeri de ortaklaşa yapılan etkinliklerin daha çok okul dışında yapılmasıdır. Yapılan bu etkinliklerin eğitim dışı etkinlikler olduğu belirmiştir. Okul içi etkinliklerin rahat ve etkili bir şekilde yapılmaması, sosyal sermayenin güven, sosyal ăg, değer ve normlar ile örgütsel bağlılık ögelerinin tam oturmamış olmasından ileri gelebilir. Ulaşılan bu bulgu doğrultusunda Töremen (2004)'in araştırma sonuçlarına bakıldığında araştırma bulguları, hediyeleşmenin çok yaygın olmadığı, ev ziyaretlerinin ve telefonla aramaların çok sık olmadığı, birlikte hareket etmedikleri ve bu durumun gelecek kaygısına dönüştüğü, birbirlerinin sırlarını çok fazla paylaşmadıkları, öğretmenler odasını sıkıcı ve itici bulmadıkları ve öğretmenler odasında sürtüşme ve çatışmaların çok fazla olmadığı şeklindedir. Araştırma sonuçlarına göre şu önerileri vermek mümkündür:

- Öğretmen ve okul yöneticilerine insan ve insan ilişkileri içerikli konferans veya seminer vb. gibi etkinliklere katılımı önerilebilir.

- Sosyal sermayenin hem değerler ve normlar hem de sosyal ağlar ögesine katk1 yapması açısından psikoloji ve sosyoloji alanlarında kitap okumalarını ve birbirleriyle sosyal ağlarla paylaşımda bulunmaları önerilebilir. 
- Okullarda sosyal sermayenin güçlü olması için okul yöneticileri liderliğinde her insanın bir değer yarattığına, her şeyin bir eksiği tamamladığına ve her olayın bir sonraki yaşanacak olaya yön vereceği düşüncesiyle kuvvet alan okul kültürü ve iklimi oluşturulabilir.

- Okul dışı etkinliklerin hem eğitim hem de eğitim haricindeki konular ile ilgili okul yöneticileri veya öğretmenler tarafından düzenlenebileceği önerilebilir.

\section{Makalenin Bilimdeki Konumu}

Eğitim Bilimleri Anabilim Dalı, Eğitim Yönetimi ve Denetimi Bilim Dalı.

\section{Makalenin Bilimdeki Özgünlüğü}

A-Hem nitel hem nicel çalışma ile sosyal sermaye kavramının incelenmiş olması.

B- Makaledeki bilgiler öğretmenlerin okullarda sosyal sermayenin yeterli olmadığı bilgisini açığa çıkarmaktadır. Bu sonuç öğretmenlerin görüşlerine göre sosyal sermaye düzeyinin artırılmasına ilişkin eksiklikleri gösterir.

C- Makaledeki bilgiler bilinmezse sosyal sermayeyi oluşturan faktörlere ilişkin öğretmenlerin algısını olumlu yönde etkilemek için yapılacak etkinliklerin neler olduğu konusunda eksiklik yaşanır.

D-Makaledeki bilgiler, okulların sahip olduğu sosyal sermayeyi güçlendirecek okul iklimi ve kültürü alanlarında kullanılır.

\section{Kaynaklar}

Allik, J., \& Realo, A. (2004). Individualism-collectivism and social capital. Journal of CrossCultural Psychology, 35(1), 29-49. 
Bourdieu, P. (1986). The Forms of capital. In John G. Richardson (Ed.), Handbook of theory and research for the sociology of education. New York: Greenwood.

Coleman, J. (1988). Social capital in the creation of human capital. American Journal of Sociolog, 94(1), 95-120.

Cooper, R., Sawaf, A. (1997). Liderlikte duygusal zeka. (Çev: Z. B. Ayman-B. Sancar). İstanbul: Sistem Yayıncılık.

Çankaya İ. H. ve Çanakçı H. (2011). Sosyal sermaye ve motivasyon arasındaki ilişkiye yönelik öğretmen görüşlerinin değerlendirilmesi. Eğitim ve Sosyal Bilimler Dergisi, $191,127-132$.

Çelik, V. (2002). Okul kültürü ve yönetimi. Ankara: Pegem A Yayınc1lık.

Ersözlü, A. (2008). Sosyal sermayenin ortaöğretim kurumlarında görev yapan ögretmenlerin iş doyumuna etkisi. (Yayınlanmamış yüksek lisans tezi), Fırat Üniversitesi Sosyal Bilimler Enstitüsü, Elazı̆̆g.

Green, J. C., Krayder, H., \& Mayer, E. (2005). Combining qualitative and quantitative methods in social inquiry. In B. Somekh \& C. Lewin (Eds.). Research methods in the social sciences (pp.275-282). London: Sage.

Güngör, G. (2011). Illköğretim okullarının öğretmen görüşlerine göre sosyal sermaye düzeyleri ve dezavantajlılıkları ile ilgili değişsenler arasındaki ilişki (Mersin İli 
Mezitli İlçesi Örneği). (Yayınlanmamış yüksek lisans tezi). Mersin Üniversitesi, Mersin.

İnce, M. ve Gül, H. (2005). Yönetimde yeni bir paradigma örgütsel bağlılık. Ankara: İleri Giden Ofset.

Karasar, N. (2002). Bilimsel araştırma yöntemi. Ankara: Nobel.

Kowch, E. G. (2004). Appreciating assets: educational technology leadership and the generation of social capital. Association for Educational Communications and Technology, 27, 503- 512.

Miles, M. B., and M. Huberman. (1994). Qualitative data analysis: a sourcebook of new methods. (2d Edition). Beverly Hills, CA: Sage Publications.

Neale, M. and Northcraft G. (1991). Factors influenciang organizational commibnent, motivation and work behaviour. New pork: McGraw HilL.

Newton, K. (2001). Trust, social capital, civil society and democracy. International Political Science Review, 22 (2), 201-214.

Orr, M. (1999). Black social capital: The politics of school reform in Baltimore. Kansas: University Press of Kansas.

Özmen, F., Aküzüm, C., Sünkür, M. ve Baysal, N. (2012). Sosyal ağ sitelerinin eğitsel ortamlardaki işlevselliği. E-Journal of New World Sciences Academy, 7 (2), 496-506.

Palgi, M., \& Moore, G. (2004). Social Capital: Mentors and Contacts. Current Sociology, 52 (3), 459-480. 
Putnam, R. (1993). Making democracy work: civic tradition in modern Italy. Princeton:

Princeton University Pres.

Şahin, C. ve Ada, Ş. (2013). İlköğretim ile ortaöğretim okullarında sosyal sermayenin kullanılma düzeyinin okul yöneticilerinin görüşleri doğrultusunda incelenmesi. Mustafa Kemal Üniversitesi Sosyal Bilimler Enstitüsü Dergisi, 10 (23), 131-153.

Töremen, F. (2002). Okullarda sosyal sermaye: kavramsal bir çözümleme. Kuram ve Uygulamada Eğitim Yönetimi, 8 (32), 568-585.

Töremen, F. (2004, Kasım). İlköğretim Kullarının Sahip Oldukları Sosyal Sermaye Konusunda Öğretmen Görüşleri (Elazlğ İli Örneği). Sözel bildiri, XIII. Ulusal Eğitim Bilimleri Kongresi, Malatya.

Woolcock, M., \& Narayan, D. (2000). Social capital: implications for development theory, research and policy. World Bank Research Observer, 15 (2), 225-249. 